\title{
Apple Fruit Removal and Limb Girdling Affect Fruit and Leaf Characteristics
}

\author{
Ido Schechter ${ }^{1}$ and J.T.A. Proctor \\ Department of Horticultural Science, University of Guelph, Guelph, Ontario N1G 2W1, Canada \\ D.C. Elfving ${ }^{2}$ \\ Horticultural Research Institute of Ontario, Vineland Station, Ontario LOR 2E0, Canada
}

Additional index words. foliar nutrition, fruit dry weight, Malus domestica, photosynthesis

\begin{abstract}
Mature apple trees (Malus domestica Borkh.) were studied in 1989 and 1990 to explore the effect of crop load on fruit dry weight (DW), dry-matter concentration (DMC), specific leaf area (SLA), and leaf C exchange, using girdled (G) and nongirdled (NG) limbs. Fruit DW and DMC decreased with heavier fruit loads. Fruit on G limbs had higher fruit DW and DMC than on NG limbs. SLA on NG limbs was unaffected by crop load, but increased dramatically on G limbs with a crop load of less than one fruit per square centimeter limb cross-sectional area. These leaves also had a low photosynthetic rate, high stomatal resistance, and high internal $\mathrm{CO}_{2}$ concentration. The results do not support the concept of feedback inhibition of photosynthesis and demonstrate specific circumstances in which the capacity of sinks to use assimilates was saturated. Exceeding this limit by significantly reducing sink strength resulted in excessive carbohydrate accumulation in leaves. Nutrient levels in leaves on G, nonfruiting limbs were generally lower than for the other treatments.
\end{abstract}

Source-sink modification in plants leads to a better understanding of the mechanisms controlling photosynthesis and dry-matter accumulation and allocation. Starch accumulation in source leaves was reported after sink removal (Herold, 1980; Schaffer et al., 1986a, 1986b), girdling (Avery et al., 1979; Heinicke, 1932; Priestley, 1976), and continuous illumination (Haapala, 1969). The results of accumulation of starch in the chloroplasts led, in some cases, to a sharp decrease in C exchange rate (CER) due to disruption of the thylakoid membranes (Schaffer et al., 1986a).

Girdling apple limbs or trees inhibited vegetative growth (Greene and Lord, 1978, 1983) and promoted the formation of flower buds, thereby increasing bloom density, fruit set, size, and yield (Dennis, 1968; Greene and Lord, 1978, 1983; Hennerty and Forshey, 1971).

Photosynthesis can adjust to demand by feedback inhibition in some plants (Azcon-Bieto, 1983; Herold, 1980; Neales and Incol, 1968), but this has not been clearly demonstrated to operate in fruit trees (Flore and Lakso, 1989). Heinicke (1932), Mika and Antoszewski (1973) and Avery et al. (1979) reported that ringing branches led to the accumulation of assimilates in leaves and the reduction of CER.

The experiments reported here examined leaf CER and drymatter accumulation in fruit and leaves on girdled $(G)$ and nongirdled (NG) limbs on mature, field-grown, fruiting $(F)$ and nonfruiting (NF) apple trees.

\section{Materials and Methods}

1989. Mature 'Sturdeespur Delicious'/MM.106 apple trees were planted in 1977 at the Horticultural Experiment Station, Simcoe, Ontario, in north-south-directed rows at a spacing of $3 \times$ $5 \mathrm{~m}$ (667 trees/ha). The soil type was a moderately well-drained

Received for publication 23 Apr. 1993. Accepted for publication 29 June 1993. This research was supported by operating grant no. A6697 of the Natural Sciences and Engineering Research Council of Canada held by J.T.A.P. We gratefully acknowledge the assistance of Dean Louttit and Wayne Pierce. The cost of publishing this paper was defrayed in part by the payment of page charges. Under postal regulations, this paper therefore must be hereby marked advertisement solely to indicate this fact.

${ }^{1}$ Present address: 185 Nahal Meshushim, Makabim D.N., Modiim 71908, Israel. ${ }^{2}$ Present Address: Tree Fruit Research and Extension Center, Washington State Univ., 1100 N. Western Ave., Wenatchee, WA 98801.
Walsher soil composed of 40 to $100 \mathrm{~cm}$ of sandy-loamy material over glaciolacustrine clay. Fertilizers, pesticides, and herbicides were applied as required, according to standard commercial practices. Sprinkler irrigation was used whenever tensiometer readings 30 and $45 \mathrm{~cm}$ deep in the orchard reached at least $-40 \mathrm{kPa}$. In spring, a trial composed of five randomized complete blocks was established. Each block contained four trees similar in size and bloom density. One tree from each block was hand-deblossomed, the second was left for natural pollination, the third was hand-pollinated during king bloom, and the fourth was hand-pollinated daily starting at about the time when $20 \%$ of the blossoms had opened until $50 \%$ of the petals had fallen. After the completion of natural (June) drop, trees in two of the four fruit-set treatments were hand-thinned to achieve fruit-set levels intermediate between zero (deblossomed) and about six to eight fruit per square centimeter limb cross-sectional area (LCSA) (daily hand-pollination). Initial fruit-set was determined for each hand-thinned tree by counting fruit on one representative limb per tree. After determining initial fruit-set per square centimeter LCSA, the proportion of fruit to remove from each tree to achieve a fruit-set between two to four fruit (natural pollination) or four to six fruit (king-bloom hand-pollination) per square centimeter LCSA was calculated. Each tree in each of these two treatments was then hand-thinned according to the calculation for that tree. After hand-thinning was completed, two representative limbs of $\approx 15 \mathrm{~cm}$ limb circumference (Forshey and Elfving, 1979) at a height of 1.0 to $2.0 \mathrm{~m}$ were chosen from each tree; one of the limbs was used as a control, while the other was girdled (28 June) after June drop $(\approx 22$ June). A 1.5-cm-wide strip of phloem and connected bark and cambial tissue was removed, and the exposed wood was protected with lanolin. On 5 Oct., every 10th shoot leaf was harvested from representative limbs, total sample leaf area was measured using an area meter (model LI-3000; LI-COR, Lincoln, Neb.), and the leaf sample was oven-dried at $80 \mathrm{C}$ to a constant weight. At harvest (5 Oct.), all fruit were collected, fresh weight (FW) and diameter of each fruit were measured, and all fruit were sliced and dried to a constant weight at $80 \mathrm{C}$. To correct for limb size differences, the data were normalized based on per-square-centimeter LCSA before statistical analysis.

On 2 Aug., a single midshoot leaf was selected randomly from each of 10 shoots on each $\mathrm{F}$ and deblossomed tree. These leaves 
were analyzed for nutrient contents by the Soil and Plant Analysis Laboratory, Univ. of Guelph. The foliar mineral nutrients N, P, K, $\mathrm{Ca}, \mathrm{Mg}, \mathrm{Mn}, \mathrm{Cu}, \mathrm{Zn}$, and Fe were calculated on a dry-weight (DW) and a leaf-area basis. The treatment arrangement for leaf characteristics was a split-plot with trees (F vs. nonfruiting NF) as the main plot and shoot (SH) leaves on NG limbs vs. SH leaves on G limbs as the subplot. When the block effect or the main plot $\times$ subplot interaction was not significant, it was pooled into the error term. Examining the significant $(P \leq 0.05) \mathrm{F} \times \mathrm{G}$ interaction across all leaf nutrients expressed on a percentage $\mathrm{DW}$ basis indicated that SH leaves on NF-G limbs reacted differently, and therefore simple effects were reported. When expressed on an area basis, only variables with significant interaction terms are presented, as explained above. CER, leaf conductance, and internal $\mathrm{CO}_{2}$ concentration $\left(\mathrm{C}_{\mathrm{i}}\right)$ were determined using a portable photosynthesis system (model LI-6200; LI-COR) as described by Schechter et al. (1994).

1990. Mature 'Delicious'/M.26 EMLA apple trees planted in 1973 at the Cambridge Research Station, Univ. of Guelph, were used in this season. Tree rows were oriented in an east-west direction, and trees were spaced at $3 \times 5 \mathrm{~m}$ on a well-drained Fox sandy loam. Twenty trees were selected for uniformity, with two G limbs on each tree on 27 June, after June drop, in a similar manner to 1989 . One additional limb on each tree served as a control. Results from the 1989 season suggested that low crop loads (zero to two fruit per square centimeter LCSA) should be examined more closely. The trees were hand thinned to different levels of crop load as in 1989. On completing the experiment on 18 Sept., all fruit and leaves were harvested from sample limbs. Leaves and fruit received the same examinations as in the previous year. In 1990, rain was well distributed and no additional irrigation was needed. To assess whether results were cultivar dependent, four additional trees each were selected from 'Empire', 'Golden Delicious', 'Spartan', 'McIntosh', and 'Idared' on M.26 EMLA in the same orchard. Four limbs were selected on each tree. Two limbs were defruited and two were allowed to carry crop. One defruited and one F limb per tree were girdled.

Fruit data for both years were analyzed quantitatively using fruit count per square centimeter LCSA as the independent variable and the other factors as dependent variables. Analyses were performed using the Statistical Analysis System (SAS) program package (SAS Institute, Cary, N.C.).

\section{Results and Discussion}

1989. Fruit on $\mathrm{G}$ limbs were heavier at similar fruit loads than fruit on NG limbs (Fig. 1). Parallel curvilinear regressions were found for both treatments, resulting in a difference of $20 \%$ to $25 \%$ in fruit DW that ranged from 10 to $25 \mathrm{~g}$, independent of fruit load. The quadratic component of the equation suggested a minimum size for fruit at high fruit loads. A correlation coefficient of $0.88(P$ $\leq 0.05, \mathrm{n}=30$ ) between fruit DW and fruit diameter showed that increases in dry matter were accompanied by increases in fruit size, as reported for apple (Hansen, 1981; Smock, 1941), nectarine (Day

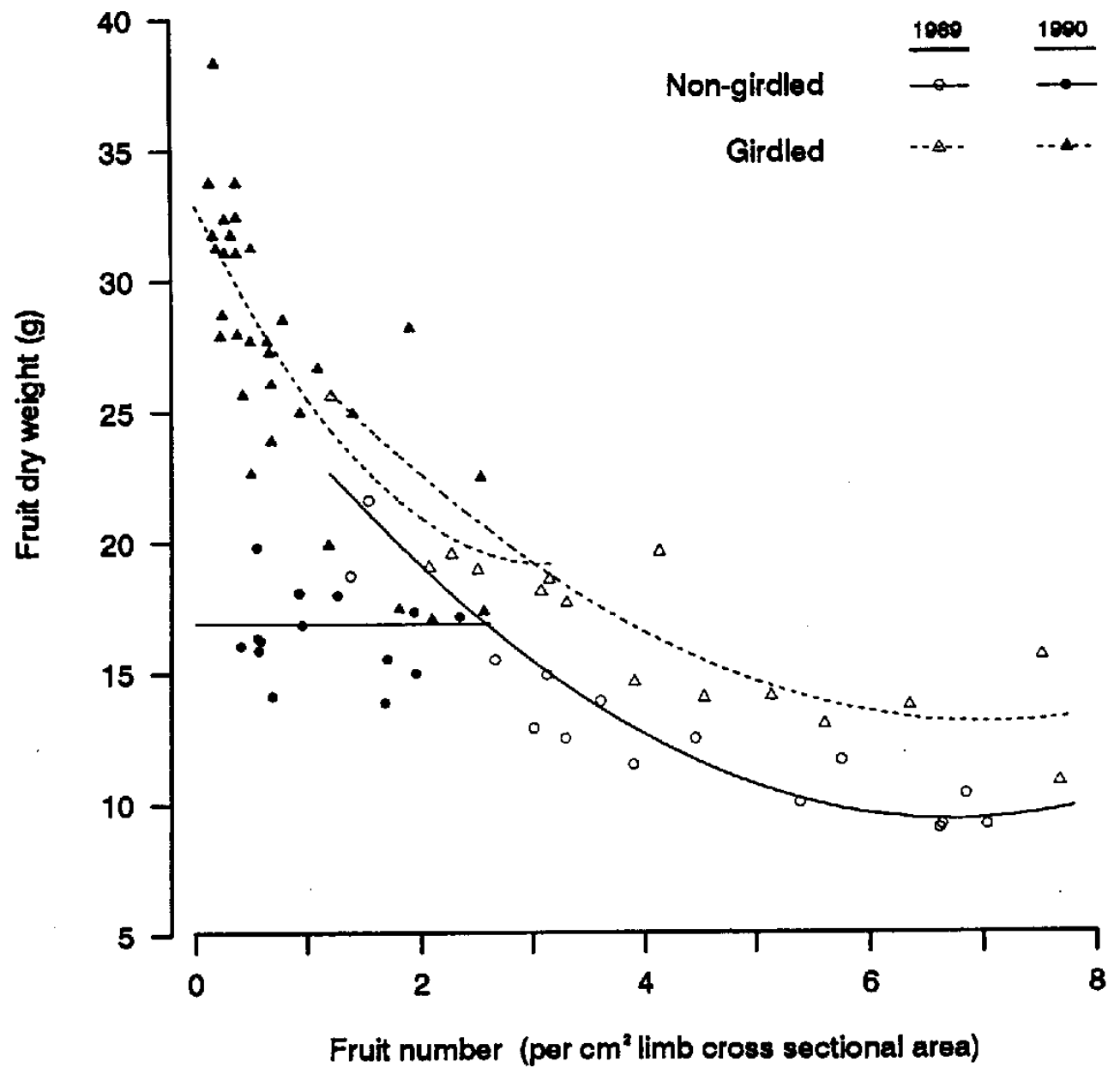

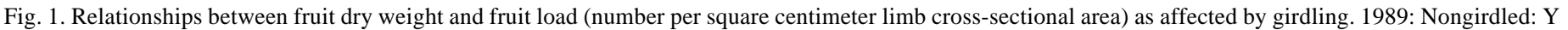

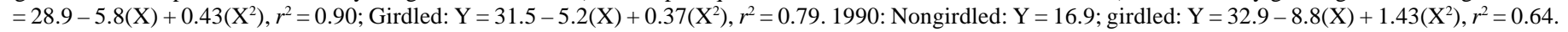


and DeJong, 1990), grapes (Vitis vinifera L.) (Winkler et al., 1974), and citrus (Cohen, 1984a, 1984b). Diameter differences between fruit on NG and G limbs were larger as fruit load increased. The regression equations are summarized: for fruit count, fruit diameter $=$ intercept - linear slope; for $\mathrm{NG}, \mathrm{Y}=7.2-0.26(\mathrm{X}), r^{2}=0.78$; for $\mathrm{G}, \mathrm{Y}=7.2-0.17(\mathrm{X}), r^{2}=0.47$. Intense competition for photosynthates in high-cropping trees affected fruit on NG limbs more than fruit on $\mathrm{G}$ limbs, which had more carbohydrates available for fruit growth.

Fruit dry-matter concentration (DMC) was higher on G limbs, but varied with fruit load in the same manner as on NG limbs (Fig. 2). The parallel equations for $\mathrm{G}$ and $\mathrm{NG}$ limbs indicate that the normal, inverse relationship of fruit size and fruit load exists even when carbohydrate export is eliminated by girdling. Girdling was done after most cell division in the fruit was completed (Blanpied and Wilde, 1968), and final fruit size may have been limited in part by the lower number of cells in fruit on heavily cropping limbs, where $\mathrm{C}$ was the limiting factor for initial fruit development (Lakso, 1986).

Specific leaf area (SLA) on NF-G limbs was very high (Fig. 3); leaves were thick, xeromorphic, and displayed unusual visible symptoms, including red venation and chlorosis. When observed under the microscope with potassium iodide/iodine dye, these leaves showed many starch grains, similar to those reported in avocado (Persea americana Mill.) leaves (Schaffer et al., 1987). Excluding NF-G limbs, enormous differences in crop load between low-cropping trees (three fruit per square centimeter LCSA, $\approx 25$ fruit/limb) and heavily fruiting trees (eight fruit per square centimeter LCSA, $\approx 115$ fruit/limb) produced no significant differences (slope not different from zero) for SLA on G or NG limbs.

Limited CER measurements on NG and G limbs on low and medium cropping trees had shown no profound or consistent differences (Schechter et al., 1994). Wood and root DW and the amount of new growth were influenced by crop load and girdling (Schechter et al., 1994).

Foliar nutrient levels were generally within the sufficient range recommended for apple production (Shear and Faust, 1980).
Nutrient concentrations in leaves on NF-G limbs were significantly below normal (Table 1). A decrease in leaf nutrient concentrations in $\mathrm{G}$ trees was also observed for peach [Prunus persica (L.) Batsch.] (Day and DeJong, 1990), orange [Citrus sinensis (L.) Osb.] (Schaffer et al., 1986a), and apple (Priestley, 1976). Foliar nutrient content data are traditionally based on percentage leaf DW. However, in this study, this method of data presentation may be misleading (Rogers et al., 1953; Priestley, 1976), since SLA differed considerably among treatments. High SLA for leaves on $\mathrm{NF}-\mathrm{G}$ limbs accounts for the apparent decrease in all foliar nutrients. A more appropriate way to express nutrient content would be on a leaf-area basis (Table 2).

On a DW basis, N, Ca, Mg, Mn, B, and Fe concentrations decreased significantly on NF-G limbs and did not differ for the other three treatments (Table 1). Similar N contents for G and NG branches (Greene, 1937) in the presence or absence of fruit (Priestley, 1976) have been reported. G limbs had a higher content of $\mathrm{N}, \mathrm{Cu}$, and $\mathrm{Fe}$ on an area basis than NG limbs (Table 2), while $\mathrm{F}$ did not affect these levels. High $\mathrm{N}$ levels can be related to the strong vegetative growth on these limbs (Hansen, 1973). As found in previous studies (Cain and Boynton, 1948; Hansen, 1973, 1980; Jentsch and Eaton, 1982), NF limbs had higher P and K concentrations than F-G and F-NG limbs when expressed either way (Tables 1 and 2). This difference is probably a result of strong vegetative growth and competition for $\mathrm{K}$ between leaves and fruit on the F limbs (Hansen, 1980). High Zn concentrations were detected on a DW and area basis for leaves on F-G limbs, and resulted in significant differences between this treatment and the other treatments. Mn levels were unaffected by girdling on an area basis but were increased by fruiting. Ca concentrations in NF-G limbs were very low, even on an area basis, and the concentration of this element was the most affected by the NF-G combination. This result agrees with that of Priestley (1976), who suggested that $\mathrm{Ca}$ depended on phloem transport. Magnesium and $\mathrm{B}$ levels on an area basis in F-G limbs were higher than in NF-G limbs.

1990. The large difference in leaf SLA and CER found between leaves on $\mathrm{NF}-\mathrm{G}$ and $\mathrm{G}$ limbs with about two fruit per square

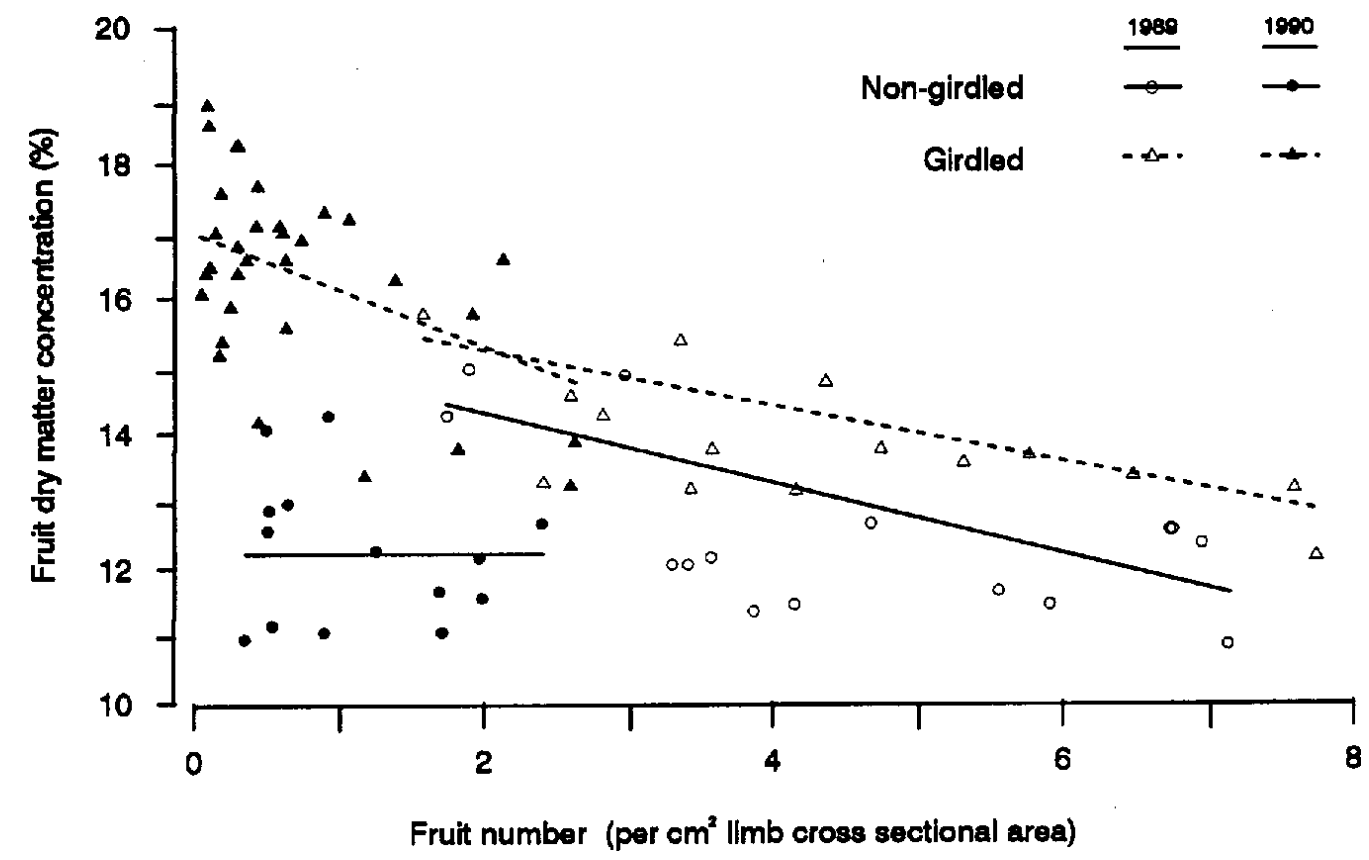

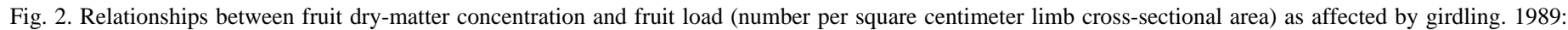
Nongirdled: $\mathrm{Y}=14.5-0.40(\mathrm{X}), r^{2}=0.45$; girdled: $\mathrm{Y}=15.5-0.34(\mathrm{X}), r^{2}=0.44 .1990$ : Nongirdled: $\mathrm{Y}=12.3$; girdled: $\mathrm{Y}=17.1-0.90(\mathrm{X}), r^{2}=0.28$. 


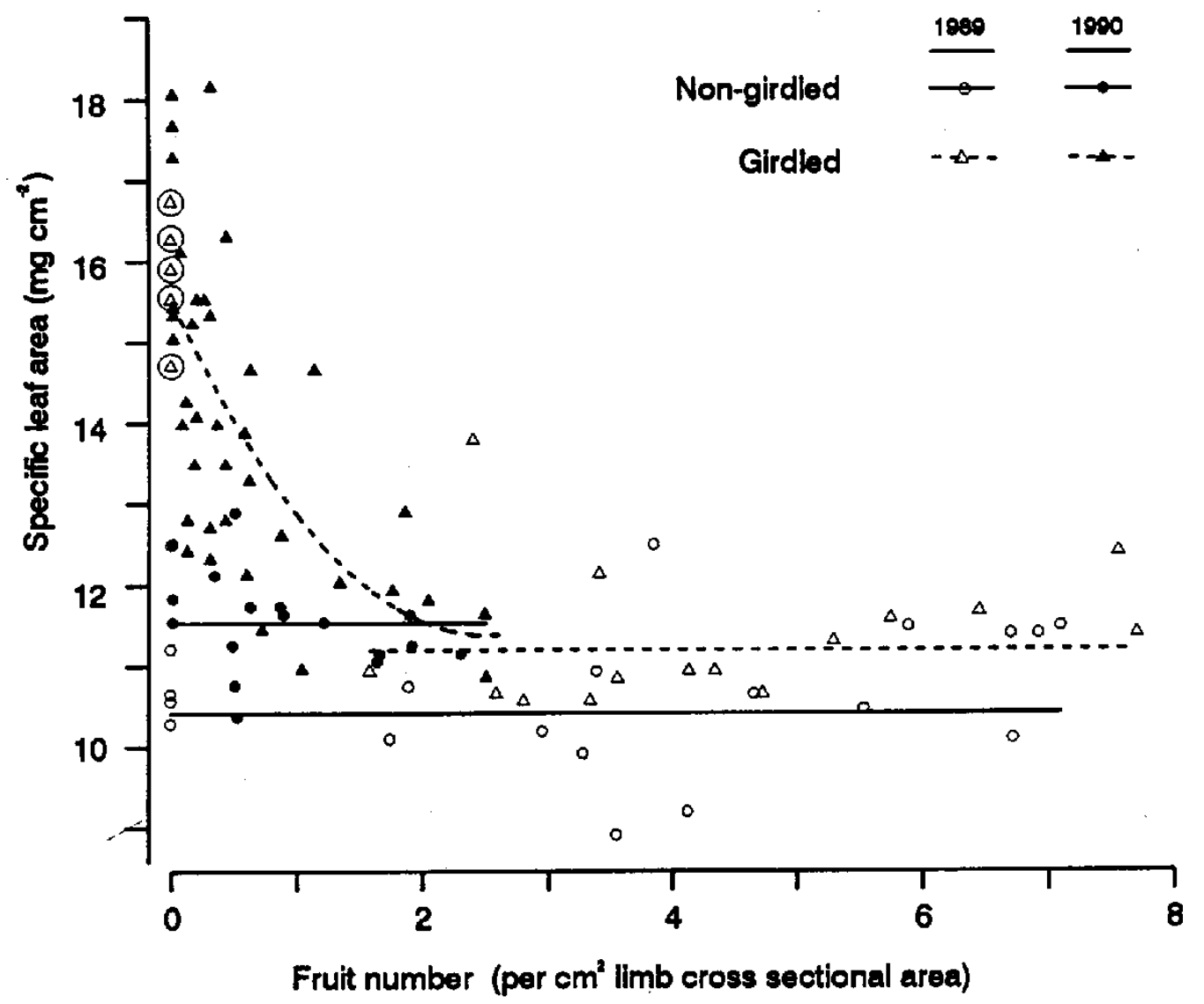

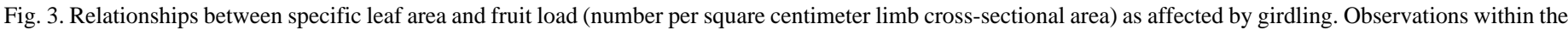

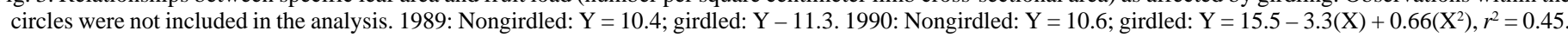

Table 1. Foliar nutrient content of apple leaves on a dry weight basis as affected by fruiting and girdling in 1989 .

\begin{tabular}{lrcccr}
\hline \hline $\begin{array}{c}\text { Tree } \\
\text { type }^{z}\end{array}$ & \multicolumn{5}{c}{ Nutrient } \\
\cline { 2 - 6 } NF-NG & $2.28 \mathrm{a}^{\mathrm{y}}$ & $0.14 \mathrm{a}$ & $1.57 \mathrm{a}$ & $1.88 \mathrm{a}$ & $0.35 \mathrm{a}$ \\
$\mathrm{F}-\mathrm{NG}$ & $2.36 \mathrm{a}$ & $0.13 \mathrm{~b}$ & $0.92 \mathrm{c}$ & $1.94 \mathrm{a}$ & $0.35 \mathrm{a}$ \\
NF-G & $1.69 \mathrm{~b}$ & $0.10 \mathrm{c}$ & $1.10 \mathrm{~b}$ & $0.98 \mathrm{~b}$ & $0.20 \mathrm{~b}$ \\
$\mathrm{~F}-\mathrm{G}$ & $2.37 \mathrm{a}$ & $0.12 \mathrm{~b}$ & $0.95 \mathrm{c}$ & $1.93 \mathrm{a}$ & $0.35 \mathrm{a}$ \\
& & & & & \\
& $\mathrm{Mn}$ & $\mathrm{Cu}$ & $\mathrm{Zn}$ & $\mathrm{B}$ & $\mathrm{Fe}$ \\
& & & $\left(\mathrm{mg} \cdot \mathrm{kg}^{-1}\right)$ & & \\
NF-NG & $96 \mathrm{a}$ & $6.20 \mathrm{ab}$ & $182 \mathrm{~b}$ & $41.2 \mathrm{a}$ & $95.8 \mathrm{~b}$ \\
$\mathrm{~F}-\mathrm{NG}$ & $117 \mathrm{a}$ & $5.80 \mathrm{ab}$ & $180 \mathrm{~b}$ & $41.6 \mathrm{a}$ & $96.6 \mathrm{~b}$ \\
NF-G & $46 \mathrm{~b}$ & $5.20 \mathrm{~b}$ & $111 \mathrm{c}$ & $25.6 \mathrm{~b}$ & $80.6 \mathrm{c}$ \\
$\mathrm{F}-\mathrm{G}$ & $101 \mathrm{a}$ & $7.00 \mathrm{a}$ & $217 \mathrm{a}$ & $41.0 \mathrm{a}$ & $124.0 \mathrm{a}$
\end{tabular}

${ }^{\mathrm{z}} \mathrm{F}=$ fruiting; $\mathrm{NF}=$ nonfruiting; $\mathrm{G}=$ girdled; $\mathrm{NG}=$ nongirdled.

yMean separation within columns by Duncan's new multiple range test $(P$ $\leq 0.05)$

centimeter LCSA in 1989 prompted this second experiment. The design concentrated on a very low fruit load of 0.1 to two fruit per square centimeter LCSA to explore the biological limit at which the total sink strength of the $\mathrm{G}$ limb was not sufficient to maintain SLA and CER levels similar to control limbs, resulting in collapse of the photosystem. Great variation in fruit DW, DMC, and SLA existed when very low crop levels were reached on $\mathrm{G}$ limbs (zero to 0.5 fruit per square centimeter LCSA, two to five fruit per limb).
These differences may have been enhanced by varying limb sizes and by a difference in the number of potential growing points, reserve levels, and vegetative sink strengths, consequently affecting fruit and leaf characteristics.

Fruit on NG limbs did not differ in their DW within this low fruit-load range and averaged $16.9 \mathrm{~g}$ (Fig. 1). Fruit on $\mathrm{G}$ limbs were larger than fruit on NG limbs and varied from $\approx 20 \mathrm{~g}$ for the one to four fruit per square centimeter LCSA up to 30 to $35 \mathrm{~g}$ for the lowest crop loads. At $\approx 0.5$ to one fruit per square centimeter LCSA, fruit accumulated DW rapidly.

Fruit on NG limbs had a mean of $12.3 \%$ DMC per fruit, while the DMC in fruit on $\mathrm{G}$ limbs increased as fruit load decreased, reaching $16 \%$ to $19 \%$ for several fruit (Fig. 2).

Leaves on $\mathrm{G}$ limbs had large increases in SLA when crop load was lower than one fruit per square centimeter LCSA, and a curve was fitted in spite of the large variation $\left(r^{2}=0.45\right)$ (Fig. 3). Leaves on NG limbs had similar SLA, independent of crop load (including zero fruit-load), and had similar SLA to leaves on G limbs with more than one fruit per square centimeter LCSA. Leaves on G limbs carrying fruit loads less than one fruit per square centimeter LCSA showed similar symptoms to those discussed in the 1989 section for leaves on NF-G limbs. Red venation and chlorosis developed first on the youngest shoot leaves, and then expanded downward on the shoot.

CER data provided similar results to those for 1989. In mid-August (temperature, $28 \mathrm{C} ; \mathrm{CO}_{2}$ concentration, $330 \mu \mathrm{mol} \cdot \mathrm{mol}^{-}$ ${ }^{1}$. liter ${ }^{-1}$; relative humidity, $45 \%$; photosynthetic photon flux, 1200 to $\left.1700 \mu \mathrm{mol} \cdot \mathrm{m}^{-2} \cdot \mathrm{s}^{-1}\right)$, significant differences $(P \leq 0.05)$ were found among leaf CER means (consisting of $10 \mathrm{SH}$ leaf measure- 
Table 2. Foliar nutrient content of apple leaves on a leaf area basis as affected by fruiting and girdling in 1989.

\begin{tabular}{|c|c|c|c|c|}
\hline \multirow{2}{*}{$\begin{array}{l}\text { Tree } \\
\text { type }^{\mathrm{y}}\end{array}$} & \multicolumn{4}{|c|}{ Nutrient $^{2}$} \\
\hline & & $\mathrm{P}\left(\mathrm{mg} \cdot \mathrm{cm}^{-2}\right)$ & $\mathrm{K}\left(\mathrm{mg} \cdot \mathrm{cm}^{-2}\right)$ & $\operatorname{Mn}\left(\mathrm{mg} \cdot \mathrm{cm}^{-2}\right) 10^{4}$ \\
\hline$\overline{\mathrm{NF}}$ & & $0.015 \mathrm{a}$ & $0.17 \mathrm{a}$ & $8.8 \mathrm{a}$ \\
\hline \multirow[t]{2}{*}{$\mathrm{F}$} & & $0.014 \mathrm{~b}$ & $0.10 \mathrm{~b}$ & $12.1 \mathrm{~b}$ \\
\hline & & $\mathrm{N}\left(\mathrm{mg} \cdot \mathrm{cm}^{-2}\right)$ & $\mathrm{Cu}\left(\mathrm{mg} \cdot \mathrm{cm}^{-2}\right) 10^{4}$ & $\mathrm{Fe}\left(\mathrm{mg} \cdot \mathrm{cm}^{-2}\right) 10^{4}$ \\
\hline NG & & $0.25 b$ & $0.64 b$ & $1.03 \mathrm{~b}$ \\
\hline \multirow[t]{2}{*}{ G } & & $0.28 \mathrm{a}$ & $0.83 \mathrm{a}$ & $1.38 \mathrm{a}$ \\
\hline & $\mathrm{Ca}\left(\mathrm{mg} \cdot \mathrm{cm}^{-2}\right)$ & $\operatorname{Mg}\left(\mathrm{mg} \cdot \mathrm{cm}^{-2}\right)$ & $\mathrm{Zn}\left(\mathrm{mg} \cdot \mathrm{cm}^{-2}\right) 10^{4}$ & $\mathrm{~B}\left(\mathrm{mg} \cdot \mathrm{cm}^{-2}\right) 10^{4}$ \\
\hline $\mathrm{NF}-\mathrm{NG}$ & $0.20 \mathrm{a}$ & 0.037 & $1.96 \mathrm{~b}$ & $4.41 \mathrm{~b}$ \\
\hline $\mathrm{F}-\mathrm{NG}$ & $0.21 \mathrm{a}$ & 0.037 & $1.93 \mathrm{~b}$ & $4.45 \mathrm{~b}$ \\
\hline $\mathrm{NF}-\mathrm{G}$ & $0.16 \mathrm{~b}$ & 0.033 & $1.78 \mathrm{~b}$ & $4.10 \mathrm{c}$ \\
\hline $\mathrm{F}-\mathrm{G}$ & $0.23 \mathrm{a}$ & 0.042 & $2.56 \mathrm{a}$ & $4.84 \mathrm{a}$ \\
\hline
\end{tabular}

${ }^{\mathrm{z}}$ Mean separation by analysis of variance $(P \leq 0.05)$ for $\mathrm{P}, \mathrm{K}, \mathrm{Mn}, \mathrm{N}, \mathrm{Cu}$, and $\mathrm{Fe}$. Mean separation within columns by Duncan's new multiple range test $(P \leq 0.05)$ for $\mathrm{Ca}, \mathrm{Mg}, \mathrm{Zn}$, and $\mathrm{B}$.

${ }^{\mathrm{y}} \mathrm{F}=$ fruiting; $\mathrm{NF}=$ nonfruiting; $\mathrm{G}=$ girdled; $\mathrm{NG}=$ nongirdled.

ments) on G limbs carrying no fruit $\left(0.25 \mu \mathrm{mol} \mathrm{CO}_{2} / \mathrm{m}^{2}\right.$ per sec $)$, 0.3 to 0.7 fruit per square centimeter LCSA $\left(3.25 \mu \mathrm{mol} \mathrm{CO}_{2} / \mathrm{m}^{2}\right.$ per $\mathrm{sec})$, and more than one fruit per square centimeter LCSA $(6.5$ $\mu \mathrm{mol} \mathrm{CO} / \mathrm{m}^{2}$ per sec). The leaves on control limbs did not differ from those on either $\mathrm{G}$ or NG limbs with one fruit or more per square centimeter LCSA $\left(6.2 \mu \mathrm{mol} \mathrm{CO} / \mathrm{m}^{2}\right.$ per sec $)$. Leaves on $\mathrm{G}$ limbs displaying low CER had high internal $C_{i}$ levels, along with stomata closure (Schechter et al., 1993). Surprisingly, despite obvious damage and low photosynthetic rates, leaves on limbs with very low fruit loads continued assimilating fast enough to increase fruit DW during most of the growing season. SLA was negatively correlated with CER on G limbs under these extreme sink-source conditions, results unlike those reported by Barden $(1977,1978)$ but similar to those reported by Monselise and Lenz (1980).

In all additional cultivars tested ('Empire', 'Golden Delicious', 'Spartan', 'McIntosh', and 'Idared'), the severe leaf symptoms described above were also developed on limbs under NF-G conditions. In a similar study with citrus leaves, Schaffer et al. (1986a) showed that the accumulation of starch granules deformed the lamellar organization of the chloroplast.

The rapid changes in leaf and fruit DW and CER at low fruit loads of $\approx 0.5$ to one fruit per square centimeter LCSA were unexpected. Extensive literature supports the feedback inhibition theory as a possible mechanism to control CER (Foyer, 1987, 1988; Neales and Incol, 1968). In the two experiments reported here, the photosynthetic source continued to function until an artificially low sink strength was reached. Dramatic changes in fruit DW, DMC, and leaf SLA were detected only when translocation from the limbs was restricted by girdling and fruit sink strength was very small, so that the vegetative (new growth and secondary thickening) and fruit sink strength combined were not able to consume photoassimilates fast enough to prevent discoloration and reduced CER in the leaves. In 1989, high CER $(\approx 20$ $\mu \mathrm{mol} \cdot \mathrm{m}^{-2} \cdot \mathrm{s}^{-1}$ ) had a rapid influence (7 days) on leaves on NF-G limbs (Schechter et al., 1994). In the 1990 season, with lower CER levels $\left(\approx 12\right.$ to $\left.14 \mu \mathrm{mol} \cdot \mathrm{m}^{-2} \cdot \mathrm{s}^{-1}\right)$, it took about three times longer before a profound CER reduction was measured. When NF limbs with vigorous shoot growth were girdled before terminal bud formation, starch accumulation developed more slowly due to greater sink activity. The results of these trials support the concept that CER in apple is not regulated by the activity of sinks.

\section{Literature Cited}

Azcon-Bieto, J. 1983. Inhibition of photosynthesis by carbohydrates in wheat leaves. Plant Physiol. 73:681-686.

Avery, D.J., C.A. Priestley, and K.J. Treharne. 1979. Integration of assimilation and carbohydrate utilization in apple, p. 221-231. In: R. Marcelle, H. Clijsters, and M. Van Poucke (eds.). Proceedings of a conference on photosynthesis and plant development. W. Junk, The Hague.

Barden, J.A. 1977. Apple tree growth, net photosynthesis, dark respiration, and specific leaf weight as affected by continuous and intermittent shade. J. Amer. Soc. Hort. Sci. 102:391-394.

Barden, J.A. 1978. Apple leaves, their morphology and photosynthetic potential. HortScience 13:644-646.

Blanpied, G.D. and M.H. Wilde. 1968. A study of the cells in the outer flesh of developing McIntosh apple fruits. Bot. Gaz. 129:173-183.

Cain, J.C. and D. Boynton. 1948. Some effects of season, fruit crop, and nitrogen fertilization on the mineral composition of McIntosh apple leaves. Proc. Amer. Soc. Hort. Sci. 51:13-21.

Cohen, A. 1984a. Citrus fruit enlargement using summer girdling. J. Hort. Sci. 59:119-125.

Cohen, A. 1984b. Effect of girdling date on fruit size of Marsh seedless grapefruit. J. Hort. Sci. 59:567-573.

Day, K.R. and T.M. DeJong. 1990. Girdling of early season 'Mayfire' nectarine trees. J. Hort. Sci. 65:529-534.

Dennis, F.G., Jr. 1968. Growth and flowering responses of apple and pear seedlings to growth restraints and scoring. Proc. Amer. Soc. Hort. Sci. 93:53-61.

Flore, J.A. and A.N. Lakso. 1989. Environmental and physiological regulation of photosynthesis in fruit crops. Hort. Rev. 11:111-157.

Forshey, C.G. and D.C. Elfving. 1979. Estimating yield and fruit numbers of apple trees from branch samples. J. Amer. Soc. Hort. Sci. 104:897900.

Foyer, C.H. 1987. The basis of source-sink interaction in leaves. Plant Physiol. Biochem. 25:649-657.

Foyer, C.H. 1988. Feedback inhibition of photosynthesis through a source-sink regulation in leaves. Plant Physiol. Biochem. 26:483-492.

Greene, L. 1937. Ringing and fruit setting as related to nitrogen and carbohydrate content of Grimes Golden Delicious. J. Agr. Res. 54:863875.

Greene, D.W. and W.J. Lord. 1978. Evaluation of scoring, limb spreading and growth regulators for increasing flower bud initiation and fruit set 
on young 'Delicious' apple trees. J. Amer. Soc. Hort. Sci. 103:208-210. Greene, D.W. and W.J. Lord. 1983. Effects of dormant pruning, summer pruning, scoring and growth regulators on growth, yield and fruit quality of 'Delicious' and 'Cortland' apple trees. J. Amer. Soc. Hort. Sci. 108:590-595.

Haapala, H. 1969. Photosynthesis and starch metabolism of chloroplasts during prolonged illumination. Planta 86:259-266.

Hansen, P. 1973. The effect of cropping on the growth and the uptake of nutrients by apple trees and different levels of nitrogen, potassium, magnesium, and phosphorus. Acta Agr. Scandinavia 23:87-92.

Hansen, P. 1980. Crop load and nutrient translocation. Acta Hort. 92:201211.

Hansen, P. 1981. Root function, leaf and fruit development in apple trees. Tidsskrift for Planteavl 85:399-404.

Heinicke, A.J. 1932. The assimilation of carbon dioxide by apple leaves affected by ringing the stem. Proc. Amer. Soc. Hort. Sci. 29:225-229.

Hennerty, M.J. and C.G. Forshey. 1971. Effects of defruiting, scoring, defoliation and shading on carbohydrate content of 'Golden Delicious' apple trees. J. Hort. Sci. 46:153-161.

Herold, H. 1980. Regulation of photosynthesis by sink activity-The missing link. New Phytol. 86:131-144.

Jentsch, D.W. and G.W. Eaton. 1982. Nitrogen fertilizer and fruit removal effects upon leaf mineral content in apple trees. Scientia Hort. 18:49-56.

Lakso, A.N. 1986. Carbon relations and early fruit growth in apple, p. 4144. In: Regulation of photosynthesis in fruit crops. T.M. DeJong (ed.). An international workshop convened at Univ. of California, Davis.

Mika, A. and R. Antoszewski. 1973. Photosynthesis and distribution of photosynthates in apple shoots treated by pinching and bark ringing. Biol. Plant. 15:202-207.
Monselise, S.P. and F. Lenz. 1980. Effect of fruit load on stomatal resistance, specific leaf weight and water content of apple leaves. Gartenbauwisschaften 45:188-11.

Neales, T.F. and L.D. Incol. 1968. The control of leaf photosynthesis rate by the level of assimilate concentration in the leaf: A review of hypotheses. Bot. Rev. 34:107-125.

Priestley, C.A. 1976. Some effects of ringing and deblossoming branches of young apple trees on leaf composition. J. Expt. Bot. 27:1325-1332.

Rogers, B.L., L.P. Batjer, and A.H. Thompson. 1953. Seasonal trend in several nutrient elements in Delicious apple leaves expressed on a percent and unit area basis. Proc. Amer. Soc. Hort. Sci. 61:1-5.

Schaffer, A.A., K.C. Liu, E.E. Goldschmidt, C.D. Boyer, and R. Goren. 1986a. Citrus leaf chlorosis induced by sink removal: starch, nitrogen, and chloroplast ultrastructure. J. Plant Physiol. 124:111-121.

Schaffer, B., J.A. Barden, and J.M. Williams. 1986b. Net photosynthesis, stomatal conductance, specific leaf weight and chlorophyll content of strawberry plants as influenced by fruiting. J. Amer. Soc. Hort. Sci. 111:82-86.

Schaffer, B., L. Ramos, and S.P. Lara. 1987. Effect of fruit removal on net gas exchange of avocado leaves. HortScience 22:925-927.

Schechter, I., D.C. Elfving, and J.T.A. Proctor. 1994. Carbon exchange rate and accumulation in limbs of fruiting and nonfruiting apple trees. J. Amer. Soc. Hort. Sci. 119:150-156.

Shear, C.B. and M. Faust. 1980. Nutritional ranges in deciduous tree fruits and nuts. Hort. Rev. 2:142-163.

Smock, R.M. 1941. Studies on bitter pit of the apple. Cornell Univ. Agr. Expt. Sta. Bul. 234.

Winkler, A.J., J.A. Cook, W.M. Kliewer, and L.A. Lider. 1974. General viticulture. Univ. of California Press, Berkeley. 